\section{Semi-in-vivo ?}

SiR,-Dr Green advocates (Nature, 229, 142 ; 1970) dispensing with the terms in vivo and in vitro which he notes are often misused as adjectives and only retain usage as adverbial phrases in the pen of the cognoscenti. Surely this is not the case-trained scientific writers use these and other terms correctly and ought not to be dubbed as cognoscenti for so doing.

He states that some editors "are prepared to turn a blind eye to the terms' suspiciously foreign sound and are prepared to admit them as current English usage. Others, more severe, by clapping the terms in italics, clearly still regard them as aliens against whom the innocent reader must be warned". Surely the italics are used for the reason that in many publications all Latin terms enjoy italics.

He says that "'semi-in-vivo' experiments have recently been threatened". It is an interesting question-perhaps Dr Green or some other reader may be able to suggest a suitable term for use when reporting results of effects obtained when human or animal tissue cultures are used in contradistinction to those obtained from direct clinical application.

Yours faithfully,

DeirdRe C. O'Donoghue-Maguire

Connaught Medical Research

Laboratories,

1755 Steeles Avenue West,

Willowdale, Ontario

\section{Expensive Meat}

SIR,-The figures for the costs of tissue cell culture media given by Dr Moore (Nature, 230, 133; 1971) need amendment. Our work ${ }^{1-3}$ has resulted in the development of defined media which makes the culture of suspended mammalian tissue cells much more predictable, and capable of much higher cell population densities and yields than was previously the case. Also, the abolition of serum from the medium has removed the most expensive ingredient which was a major obstacle to large scale culture.

A comparison of the costs of media is given in the Table.

Our costs are based on that of fine laboratory chemicals, hence for large scale usage the cost could be very much less. Also we know that yields could be considerably increased. Whether or not these costs would be comparable with that of best beef is at least debatable. On the grounds of rates of production there would be an enormous gain by the use of cell culture. Under optimum conditions in continuous-flow culture the cell mass will reproduce itself in 4 days in defined medium, whereas I believe it takes about two years to produce a crop of bullocks. Dr Moore also seems to imply that there would be an ethical problem about meat production by tissue culture. But surely tissue cell culture could be the only solution to the ethical problems raised by modern battery production of farm animals.

Yours faithfully,

$$
\text { S. J. PIRT }
$$

Microbiology Department,

Queen Elizabeth College,

University of London

${ }^{1}$ Birch, J. R., and Pirt, S. J., J. Cell Sci., 7, 661 (1970).

${ }^{2}$ Blaker, G. J., and Pirt, S. J., J. Cell Sci., 8 (1971).

${ }^{3}$ Blaker, G. J., Birch, J. R., and Pirt, S. J., J. Cell Sci. (in the press).

\title{
Obituaries
}

\section{Dr Geoffrey Bourne}

Geoffrey Bourne, physician and cardiologist of St Bartholomew's Hospital, London, and author of a number of medical books, died in December 1970 at the age of seventy-seven.

After entering St Bartholomew's Hospital in 1912 with an entrance scholarship in arts, his very great ability was immediately shown when he won almost all the scholarships and prizes that were available. His distinguished career at the hospital continued until his retirement in 1959 , and can best be summed up by the final words of his own book, We Met at Barts (1963), as "forty-seven years of association with an institution that had given me countless blessings, no regrets, wonderful friends and a professional experience beyond price".

As a physician and cardiologist, Geoffrey Bourne wrote many original papers contributing to the advancement of medical knowledge. He also sensed that heart patients would benefit from an explanation in lay terms of the problems of heart disease-his book Heart Disease has been a great help to many people. In addition, his qualities as a physician included a great ability to observe and remember the patients of the hospital.

He was an active member of the British Cardiac Society, an interest that continued until the time of his death. His long association with the United States, which started with a Rockefeller Fellowship and which was strengthened by his happy marriage to Margherita Contonio of New Orleans, led him to found the Horseshoe Club to promote Anglo-American fellowship and the interchange of medical men between the two countries.

As a teacher of medicine, Geoffrey Bourne won great affection. His skill and interest are exemplified in his book The Principles of Clinical Pathology in Practice. His insight into the teaching methods of others made him concentrate on establishing his own diagnoses on fundamental principles and his affection for his students made him give much time to the Barts Journal.

Outside the realms of medicine he was equally outstanding. His interests included music and painting and his performance in both these spheres gave much pleasure to others. He was a keen fly fisherman and his interest in natural history and country lore was centred largely round the cottage in Sussex where he spent many happy months over a period of fifty years. At the time of his death, he was finishing a book about this part of his life. An earlier book, Return to Reason (1942), showed his desire to bring sanity into politics.

After the death of his first wife in 1952 , he married Patricia McCready who brought further happiness to his home life and who helped him to write the books for which they will both be so well remembered. In recording his skill, understanding and love for future generations, these books will temper the sense of loss shared by the thousands who were lucky enough to have been in personal contact with him.

\section{Mr C. R. Barber}

MR C. R. BARBER, a leading authority on temperature measurement and one of the principal architects of the Inter- 